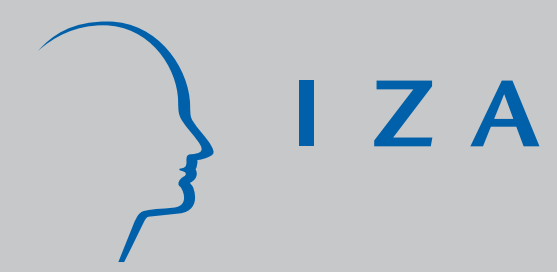

IZADP No. 1982

Is Demand-Pulled Innovation Equally Important in Different Groups of Firms?

Mariacristina Piva

Marco Vivarelli

February 2006 


\title{
Is Demand-Pulled Innovation Equally Important in Different Groups of Firms?
}

\author{
Mariacristina Piva \\ Catholic University of Piacenza \\ Marco Vivarelli \\ Catholic University of Piacenza, CSGR Warwick, \\ Max Planck Institute of Economics Jena and IZA Bonn
}

Discussion Paper No. 1982

February 2006

IZA
P.O. Box 7240
53072 Bonn
Germany

Phone: +49-228-3894-0

Fax: +49-228-3894-180

Email: iza@iza.org

\begin{abstract}
Any opinions expressed here are those of the author(s) and not those of the institute. Research disseminated by IZA may include views on policy, but the institute itself takes no institutional policy positions.

The Institute for the Study of Labor (IZA) in Bonn is a local and virtual international research center and a place of communication between science, politics and business. IZA is an independent nonprofit company supported by Deutsche Post World Net. The center is associated with the University of Bonn and offers a stimulating research environment through its research networks, research support, and visitors and doctoral programs. IZA engages in (i) original and internationally competitive research in all fields of labor economics, (ii) development of policy concepts, and (iii) dissemination of research results and concepts to the interested public.
\end{abstract}

IZA Discussion Papers often represent preliminary work and are circulated to encourage discussion. Citation of such a paper should account for its provisional character. A revised version may be available directly from the author. 
IZA Discussion Paper No. 1982

February 2006

\section{ABSTRACT \\ Is Demand-Pulled Innovation Equally Important in Different Groups of Firms?*}

Previous empirical literature - mainly cross-sectional - has tested the demand-pull hypothesis and found that overall, evidence does not conflict with the idea that innovation may be driven by output. Using a balanced panel of 216 Italian manufacturing firms over the 1995-2000 period, and checking for fixed effects, time, sectoral and size dummies and for the pathdependent nature of R\&D, we also find a (barely significant) role of sales in inducing R\&D expenditures. However, at the micro level, the demand-pull effect plays a varying role for the different sub-samples of firms. In particular, exporting firms, those which are liquidityconstrained, those not receiving public subsidies and those not heading a business group, seem to be particularly sensitive to sales in deciding their R\&D expenditures. These microeconometric results have been obtained using a Least Squares Dummy Variable Corrected (LSDVC) estimator, a recently-proposed panel data technique particularly suitable for small samples.

JEL Classification: $\quad$ O31

Keywords: $\quad$ R\&D expenditures, demand-pull, innovative firms, LSDVC estimator

Corresponding author:

Marco Vivarelli

Facoltà di Economia

Università Cattolica

Via Emilia Parmense 84

I-29100 Piacenza

Italy

Email: marco.vivarelli@unicatt.it

\footnotetext{
"This paper is part of the research project: "Domanda, innovazione e dinamica industriale" (MIUR prot. n. 2003137229); financial support from MIUR is gratefully acknowledged. Alessandra Catozzella provided excellent research assistance.
} 


\section{Introduction}

That rising demand may induce an increase in the innovation effort is a rather old issue (Schmookler, 1962 and 1966). On the one hand, increasing sales permit the financing of expensive and uncertain $R \& D$ activities, while on the other the appropriability and potential profitability of innovation rise with market size (Schumpeter, 1942).

Previous empirical literature (see Section 2) has provided evidence supporting demandpulled innovation both at the aggregate level (entire economy and industrial sectors) and at the microeconomic (firm) level. However, previous analyses seem to be affected by two main limitations.

First, most of these studies use cross-section analyses, so focusing mainly on the between differentials, possibly affected by fixed effects, which may be either sectoral or firm specific, and by endogeneity problems. A novelty of this paper is to propose a dynamic specification of the demand-pull hypothesis at the firm level which takes into account both the within and the between effects across 216 Italian manufacturing firms over a period of six years (1995-2000). Based on the merging of two questionnaire surveys, the availability of a panel dataset permits us to wipe out possible firm-specific fixed effects and to deal both with endogeneity and with the path-dependent, persistent nature of innovation. The adoption of a recently-proposed panel data technique suitable for small samples is another novelty of this paper (see the methodological discussion in Section 3).

Second, previous microeconometric evidence at the level of the firm did not distinguish between different groups of firms characterised by particular features which can make the demandpull impact more or less effective. Examples include the hypothesis that liquidity-constrained firms should be more reactive to sales than firms which do not have any kind of difficulty in raising external funds and obtaining bank credit. By the same token, innovation should be much more sensitive to demand evolution in firms which do not receive any kind of public subsidy in comparison with their counterparts enjoying public support to conduct R\&D activities. Hence, a further novelty of this paper is to examine whether demand-pulled innovation is equally important for different categories of firms or, rather, particularly crucial in some of them.

The paper is organized as follows: in the next section previous literature is critically discussed; our new unique database will be described and some methodological issues will be discussed in Section 3; Section 4 will propose a taxonomy of firms which should be more sensitive to the demand-pull inducement mechanism and will discuss the results from the panel analysis, both in aggregate and as applied to the different groups of firms; Section 5 will briefly conclude. 


\section{Previous Literature}

From an empirical point of view, the demand-pull hypothesis was initially tested at the sectoral level. In particular, Schmookler (1966), using US sectoral data, showed that the more investment there was in a user industry at a given time, the more patented capital goods innovation one observed in the supplying industry some time later. Contrary to what is commonly thought, Schmookler was aware of the role of different technological opportunities (what later came to be called the technology-push hypothesis, see Rosenberg, 1976 and 1982; Dosi, 1988 ${ }^{1}$ ), and found that firms in "science-based industries" produced much more innovation for a given amount of sales than firms in other sectors. More in general, the demand-pull hypothesis needs to be checked for the different technological regimes which characterise the different industrial sectors. Indeed, the so called "sectoral systems of innovation" differ in terms of market structure, opportunity and appropriability conditions, spillovers, and so on (see Freeman, 1982; Pavitt, 1984; Malerba and Orsenigo, 1996; Malerba, 2005). As far as econometric studies are concerned, an adequate consideration of sectoral peculiarities in innovation activity calls for the implementation of pathdependence (see Section 3), for the inclusion of sectoral dummies and for the running of separate sectoral regressions (see Section 4).

Further tests of Schmookler's hypothesis took this lesson into account. For instance, Scherer (1982) confirmed the correlation between capital goods patenting and using industry investment, after checking for seven technology class dummies in the US; indeed, the consideration of differences in technological opportunities gave rise to a large increase in the fitness of his regressions.

While both Schmookler and Scherer used patent statistics, Kleinknecht and Verspagen (1990) rightly underlined that there is generally a lag between innovation and final patenting (see Archibugi and Pianta, 1996; Smith 2005). If this is the case, the time span between investment (sales) in the user industry and patenting in the supplying industry may actually correspond to a simultaneous occurrence of innovation and increasing sales within the firms in the supplying industry. Here an important methodological problem arises: it can be rightly argued that innovative activity itself increases demand because of the accelerator effects associated with decreasing prices due to process innovation and/or increasing market share due to product innovation. Thus, high correlations between demand and innovative evolution may be affected by an endogeneity problem.

\footnotetext{
${ }^{1}$ For surveys of the demand-pull vs technology-push debate and of more recent related models, see Stoneman (1979), Von Tunzelmann (1990), Vivarelli (1995), Antonelli (1998).
} 
Using data on 46 Dutch sectors, Kleinknecht and Verspagen (1990) found evidence of a significant relationship between $R \& D$ growth and demand growth; however, this correlation cannot be seen simply as confirmation of the unidirectional demand-pull hypothesis, since their results showed a mutual dependence of demand and innovation.

The endogeneity problem in the relationship between demand and innovation may also arise at the macroeconomic level; for example, Geroski and Walters (1995), using macroeconomic time series for the UK, found significant evidence that output caused innovation and patents, but no evidence of the reverse effect.

Most recent studies have focused on the level of the firm, using microdata. The main advantage of working at this level of analysis is the opportunity to better measure innovation activity and to avoid composition effects which may easily arise at the sectoral and, a fortiori, at the macroeconomic level. However, microeconometric tests have to take into account the strong pathdependence of innovative activity (i.e. technology push at firm level) and the obvious presence of important fixed effects related to different managerial capabilities and other firm-specific characteristics.

Using Community Innovation Survey (CIS) data from about 8,000 Dutch firms with 10 or more employees in the period 1990-92, Brouwer and Kleinknecht (1996) found that demand growth in the three-year period induced an increase in innovation output in 1992, measured both in terms of products new to the firm and products new to the sector. In a later study, the same authors (Brouwer and Kleinknecht, 1999) merged the CIS 1992 survey with a previous national survey conducted in 1988, obtaining a panel of 441 firms having positive R\&D expenditure in both years. By running regressions in changes of logs (so wiping out fixed effects), using demand growth in a firm's sector of principal activity, and controlling for different technological opportunities (technology-push), the authors found a significant confirmation of the demand-pull hypothesis at the level of the firm.

Similarly, Crépon, Duguet and Mairesse (1998) - using data from a French innovation survey covering 4,164 innovative firms over the period 1986-90 - found some evidence that the probability of engaging in $R \& D$, the $R \& D /$ capital intensity, patent numbers and innovative sales were all positively correlated with both demand-pull and technology-push indicators ${ }^{2}$.

The main limitation of the microeconometric studies above is their lack of a continuous time dimension in the datasets used and so their inability to put forward dynamic panel data models. From this respect, the paper by Hall, Mairesse, Branstetter and Crépon (1999), although only based on bivariate causality regressions and not specifically addressed to test the demand-pull hypothesis, is particularly useful to our analysis from at least two points of view. First, when using panel data 
for French, Japanese and US high-tech firms, they found that sales growth clearly led to R\&D growth in all the countries studied, while the reverse effect was not significant in two countries and very small in the remaining one (US). Thus, this microeconometric evidence was clearly in support of the demand-pull hypothesis.

Second, the authors found that R\&D in US firms appear to be more sensitive, i.e. shows larger estimated coefficients, to past sales and cash flow, than their French and Japanese counterparts. The speculative interpretation provided by the authors is suggestive: softer budget constraints in France and Japan would result in a lower sensitivity to market signals, while the higher cost of external capital in the US would imply a larger explanatory power of the demand-pull approach $^{3}$. This is an important suggestion of the possible role of liquidity constraints in fuelling the demand/innovation relationship (see Section 4). Unfortunately, constraints in their aggregate data sources did not allow the authors to directly investigate the role of credit rationing and other firm characteristics in determining the scope of the demand-pull effect.

On the whole, the existing - still limited - empirical literature which has attempted to investigate the demand-pull hypothesis at the level of the firm, has never used cross-section plus time-series datasets based on questionnaire surveys providing additional information about different firms' features. Since firms are heterogeneous, the basic hypothesis to be tested in this study is that demand-pulled innovation may be more or less important in different categories of firms. This issue will be fully investigated through a differentiated panel analysis; to our knowledge, this is the first attempt to test the validity of the demand-pull hypothesis across different groups of firms.

\section{Data and Methodology}

The main constraint in the study of the link between sales and R\&D investment is the lack of suitable databases aimed at measuring the two variables over a time-series dimension. In this regard, we had the opportunity to build a new database derived from the questionnaire surveys developed originally by the investment bank Mediocredito Centrale (MCC, now Capitalia) and involving representative samples of Italian manufacturing firms with no less than 11 employees. The original MCC database comes from two different questionnaire waves, each of them collecting contemporary and retrospective (previous three years) data from samples of more than four

\footnotetext{
2 These indicators were dummy variables based on firm's own self-assessment (see also Barlet, Duguet, Encaoua and Pradel, 1998).
} 
thousand firms ${ }^{4}$. In order to obtain a balanced panel dataset for studying the demand-pull hypothesis, we merged the two waves (1995-2000) and kept only the overlapping firms declaring continuous data on $R \& D$ expenditures and sales. We ended up with a panel of 216 manufacturing firms over a 6-year period.

As already mentioned, in this paper innovation is measured using the value of $R \& D$ expenditures declared by the firms ${ }^{5}$, while demand is measured by sales. Monetary variables are expressed at 1995 constant prices; some descriptive statistics are given in Table 1.

\section{Insert Table 1}

Estimates will test the following specification for firms (i) over time $(t)$ :

$$
R D_{i, t}=\alpha R D_{i, t-1}+\beta_{1} \text { sales }_{i, t}+\beta_{2} \text { sales }_{i, t-1}+\left(\eta_{i}+v_{i, t}\right) \quad i=1, \ldots, N ; t=1, \ldots, T
$$

where variables are expressed in natural logarithms, $\eta$ is the idiosyncratic individual and time-invariant firm's fixed effect and $v$ the usual error term ${ }^{6}$. In addition, a full set of time and sectoral dummies have been introduced into the analysis.

The reasons for taking the lagged dependent variable as a first regressor into consideration are both econometrical and interpretative. From a methodological point of view, the revealed persistence of the $R \& D$ variable $(\rho=0.79)$ calls for a necessary AR(1) check. From an interpretative point of view, since the seminal contribution by Atkinson and Stiglitz (1969), economists of innovation have known that R\&D investment is path-dependent (David, 1985; Arthur, 1988) and cumulative (Nelson and Winter, 1982; Dosi, 1988; Ruttan, 1997), and so any explanation of present innovative activity necessarily involves considering the role of previous innovative activity. This is also true at the level of a particular firm: innovation moves along a "technological trajectory" and R\&D investment is characterised by structural inertia and cumulative complementarities

\footnotetext{
${ }^{3}$ On the liquidity constraints imposed by active share markets, hostile takeover activity and frequent use of the "exit" option in the Anglo-Saxon countries compared with Japan and continental Europe, see Franks and Mayer (1990), Kester, (1992) and Hall (1994).

${ }^{4}$ Apparently very attractive for research purposes, these surveys are however characterised by many missing values; moreover, the sample overlapping across waves is unfortunately rather small.

${ }^{5}$ Like other alternative measures of innovative activity (see Patel and Pavitt, 1995; Archibugi and Pianta, 1996), R\&D expenditures suffers from some drawbacks such as the underestimation of innovation within small firms. As is obvious from the following Table 1, our sample is made up of medium and large firms where innovation is likely to be formalized in R\&D investment. Moreover, there were two additional reasons for using R\&D expenditures: 1) it was the only quantitative data available throughout the 6 years and for all the 216 firms; 2) in contrast with patents and innovation, R\&D is an "ex-ante" measure of innovative activity, so mitigating a possible problem of endogeneity with respect to the sales variable (see Section 2 and the discussion below in this section).
} 
(Bresnahan, Brynjolfsson and Hitt, 2002; Colombo and Delmastro, 2002; Dosi, Levinthal and Marengo, 2003).

Once we have checked for lagged $R \& D$, current and lagged sales have to be considered in order to test our basic demand-pull hypothesis ${ }^{7}$. Here, a possible endogeneity problem may arise, as discussed in the previous section. However, our dependent variable measures an initial, preinnovation investment in $R \& D$, with $R \& D$ expenditures having an uncertain and delayed outcome in terms of subsequent innovation (Griliches, 1979 and 1995; Patel and Pavitt, 1995). Since only subsequent successful innovation can have an impact on sales and market share, the possible reverse effect is not between present $R \& D$ expenditures and present sales, but between future successful innovation and future sales ${ }^{8}$. This makes the possible insurgence of endogeneity with regard to our demand regressors extremely unlikely ${ }^{9}$.

However, the need for considering the lagged dependent variable implies another obvious problem of endogeneity. A natural solution for first-order dynamic panel data models is to use GMM (General Method of Moments; see Anderson and Hsiao, 1981; Arellano, 1989; Arellano and Bond, 1991; Arellano and Bover, 1995; Blundell and Bond, 1998). Unfortunately, this method is only efficient asymptotically and is not suitable for small samples (such as the ones used below, when the analysis is applied to sub-groups from the original 216 firms).

Therefore we have used a method recently proposed by Kiviet (1995 and 1999), Judson and Owen (1999), Bun and Kiviet (2001 and 2003) and extended by Bruno (2005a and 2005b) to unbalanced panels. This method has been proposed as a suitable panel data technique in the case of small samples where GMM cannot be applied efficiently. Let us suppose we have a standard autoregressive panel data model, based on the possibility of collecting observations over time and across individuals; our problem can then be described as follows:

$y=D \eta+W \delta+v$

\footnotetext{
${ }^{6}$ Under the assumption that the disturbances are independent across firms.

${ }^{7}$ Of course, it would have been better to take lags of higher degree of our main impact variable (Sales) into account; unfortunately, when dealing with short panels, a trade-off exists between the implementation of further lags and the acceptable extension of the time dimension of the used dataset.

${ }^{8}$ Moreover, it is reasonable to assume that the final market effect (feedback) of current R\&D expenditures on sales can be detected well above the short time dimension of the panel used in this study.

${ }^{9}$ Consistently with this conclusion, the Arellano-Bond estimator - used for initialising the adopted econometric procedure, see below - on the overall sample of 216 firms does not accept the assumption of endogeneity of sales; in fact, the correspondent Sargan test rejects the null hypothesis of validity of instruments under the assumption of endogeneity of sales $\left(\chi^{2}(17)=30.12^{* *}\right)$.
} 
where $y$ is the vector of observations for the dependent variable, $D$ is the matrix of individual dummies, $\eta$ is the vector of individual effects, $W$ is the matrix of explanatory variables including lagged dependent variable, $\delta$ is the vector of coefficients, and $v$ the usual error term.

The LSDV estimator is the following:

$\delta_{L S D V}=\left(W^{\prime} A W\right)^{-1} W^{\prime} A y$

where $\mathrm{A}$ is the within transformation which wipes out the individual effects.

Since the LSDV estimator is not consistent, a more accurate measuring of its bias can be seen as the first step towards correcting it. The LSDV bias is given by:

$$
E\left(\delta_{L S D V}-\delta\right)=c_{1}\left(T^{-1}\right)+c_{2}\left(N^{-1} T^{-1}\right)+c_{3}\left(N^{-1} T^{-2}\right)+O\left(N^{-2} T^{-2}\right)
$$

For the analytical expression of the terms in formula (4) see Bun and Kiviet (2003, p.147).

In their Monte Carlo simulations Bun e Kiviet (2003) and Bruno (2005a) consider three possible nested approximations of the LSDV bias which in turn are extended to the first, second and third terms of $(4)^{10}$. In this study we will correct for the most comprehensive and accurate one ${ }^{11}\left(\mathrm{~B}_{3}\right.$ in Bun and Kiviet (2003) and Bruno (2005a) notations). Therefore in the following, the LSDV corrected estimator (LSDVC) is equal to:

$L S D V C=L S D V-B_{3}$

The Monte Carlo experiments (see Kiviet, 1995; Judson and Owen, 1999; Bun and Kiviet, 2001) show that the LSDVC estimator, in small samples, outperforms consistent IV-GMM estimators such as the Anderson-Hsiao and Arellano-Bond.

The procedure has to be initialised by a consistent estimator to make the correction feasible, since the bias approximation depends on the unknown population parameters. Three possible

10 In particular, with an increasing level of accuracy: $B_{1}=c_{1}\left(T^{-1}\right) ; \quad B_{2}=B_{1}+c_{2}\left(N^{-1} T^{-1}\right)$; $B_{3}=B_{2}+c_{3}\left(N^{-1} T^{-2}\right)$. 
options for this purpose are the Anderson-Hsiao, Arellano-Bond and Blundell-Bond estimators. In this study, we will initialise the bias correction with the Arellano-Bond estimator, here considered as the best established panel data estimator implemented in the STATA econometric package used $^{12}$.

Bun and Kiviet (2001) derive the asymptotic variance of the LSDVC for N large. However, the estimated asymptotic standard errors may provide poor approximations in small samples, generating possibly unreliable t-statistics; while bootstrap methods generally provide approximations to the sampling distribution of statistics which are at least as accurate as approximations based upon first-order asymptotic assumptions (see also Bruno, 2005b). Accordingly, in this study the statistical significance of the LSDVC coefficients has been tested using bootstrapped standard errors (100 iterations).

In the next section aggregate and sub-group estimates are run using OLS, LSDV and LSDVC estimates. The first are affected by both fixed effects and endogeneity; the second wipe out fixed effects ${ }^{13}$; the third also take into account the endogeneity of the lagged R\&D variable. While OLS and LSDV are reported for completeness, comments will be based on the outcomes from the more reliable LSDVC estimates only.

\section{Hypotheses to Be Tested and Results}

First, the demand-pull hypothesis will be tested in general using all the 216 firms which constitute our dataset (for a total of 1,296 observations). Taking for granted the explicative significant effect of the lagged $R \& D$ variable along a firm's specific technological trajectory, the

\footnotetext{
${ }^{11}$ In their conclusions Bun and Kiviet (2003, pp.151-2) suggest a lower order correction when both $\mathrm{N}$ and $\mathrm{T}$ are twodigit numbers; however this is not the case in this paper where $\mathrm{T}$ is equal to 6 .

${ }^{12}$ It should be noted that the three alternative procedures are asymptotically equivalent. See Bruno (2005b, pp. 5 and ff.) for instructions on Stata command xtlsdvc.

${ }^{13}$ In our analysis we wipe out all the firms' time-invariant fixed effects (such as ownership structure, group belonging, managerial capabilities, financial leverage and so on) that can influence a firm's incentive to engage in R\&D investment and which may explain why only some firms are innovative (see Veugelers, 1997; Cassiman and Veugelers, 2002). While this is an important stream of literature in explaining both the R\&D and the cooperative R\&D decisions in a static, cross-sectional framework (see Colombo and Garrone, 1996; Piga and Vivarelli, 2003 and 2004), in this work only innovative firms are considered, and these fixed effects are deliberately excluded in order to test only the (time variant) demand-pull hypothesis through a dynamic specification. However, some of these firms' specific characteristics will be used in the subsequent analysis as splitting variables in singling out groups of firms where demand-pulled innovation may be more or less significant.
} 
main point is to see whether increasing demand has a role in inducing higher R\&D investment both in the short and in the long run ${ }^{14}$.

The rest of the analysis will be devoted to discovering possible significant differences in the role of demand-pulled innovation within different groups of firms. Bearing in mind issues raised in the literature and the information actually available from our questionnaire, the following hypotheses will be tested:

a) Since foreign markets are exposed to tighter competition, exports should constitute a key component of demand evolution and a more significant stimulus to innovation (see Begg, Dalum, Guerrieri and Pianta, 1999; Pianta, 2001); hence firms producing higher percentages of exported goods should exhibit a higher innovation/sales elasticity.

b) As suggested by Hall, Mairesse, Branstetter and Crépon (1999), firms affected by liquidity constraints and credit rationing should be more dependent on internal cash flow and so should be more sensitive to current sales when deciding to engage in $R \& D$ investment (see also Goodacre and Tonks, 1995; O’Sullivan, 2005) ${ }^{15}$.

c) For similar reasons, firms benefiting from public subsidy should be less sensitive to current sales, since they have an alternative source of funding to fuel innovation (see Cordes, 1989; Kleinknecht and Reijnen, 1992).

d) Firms heading a business group have more opportunities for increasing liquidity, financing R\&D projects and sharing the uncertainty implied by innovation activities (see Filatotchev, Piga and Dyomina, 2003), so they should be less constrained by their own sales in deciding how much funding to devote to R\&D investment.

e) For similar reasons, diversified firms should be more confident in engaging in activities with uncertain and delayed returns even in the absence of increasing sales because they can rely on a portfolio of future innovative products and they can take advantage from both the

\footnotetext{
${ }^{14}$ In our context "long-run" elasticity takes into account the impact of both current and lagged sales according to the formula $\frac{\beta_{1}+\beta_{2}}{1-\alpha}$ (long-run multiplier, see Verbeek, 2004, pp.311).

${ }^{15}$ According to the information collected in the questionnaire, liquidity-constrained firms are those that replied 'yes' to one, two or three of the following questions: "Would the firm, at the current interest rate, have asked for more credit? "In order to have more credit, would the firm have paid a slightly higher interest rate?" and "Has the firm asked for a higher credit line without obtaining it?”
} 
possibility of risk-sharing over different markets and from the internalization of possible inter-product positive innovation spillovers (see Henderson and Cockburn, 1996).

f) As far as firm's size is concerned, the prediction is ambiguous: on the one hand, large firms should be less financially constrained and more confident regarding their possibility to share costs and risks over a large amount of output (see Cohen and Klepper 1996), and so they should be influenced to a lesser extent by current sales. On the other hand, one can well sustain that only large firms have their own $R \& D$ departments performing formalized $R \& D$ activities (see Kamien and Schwartz, 1982; Cohen and Levin, 1989; Acs and Audretsch, 1990; Cohen, 1995) and so only large firms make rational R\&D planning decisions, based on the consideration of current sales. At the other end of the size spectrum, smaller firms are characterized by a much more occasional and erratic R\&D activity. If such is the case, the demand-pull hypothesis should be more appropriate for large firms rather than for their smaller counterparts.

g) With regard to sector belonging, once the autoregressive nature of $R \& D$ has been taken into account, there are no particular a priori reasons to think that some sectors should be more sensitive to demand-pull than others; however, the insurgence of possible differences across sectors will be tested, and in any case regressions will be checked for sectoral fixed effects in order to take into account the different technological opportunity and appropriability conditions which characterize the different "sectoral systems of innovation" (see the discussion at the beginning of Section 2).

Results are reported in Tables 2 to 9.

\section{Insert Table 2}

Table 2 presents the OLS, LSDV and LSDVC outcomes, as do all the following tables. In all tables both OLS and LSDV estimates exhibit a satisfactory fit (see R squared and F tests), although the discussion in the previous section informs us that reliable results are provided only by the third estimates, initialised by the Arellano-Bond estimator to get accuracy of approximation of bias $\mathrm{B}_{3}$ and characterised by bootstrapped standard errors. Hence, comments will be based only on LSDVC estimates, considering both the short-term impact of current sales and the long-term effect combining the impacts of both current and lagged sales. All the 
estimates are checked both for time (in order to take into account possible aggregate and cyclical effects), $\operatorname{size}^{16}$ and sectoral dummies ${ }^{17}$. As is immediately clear, all the estimates reported in the tables are affected by a strong path-dependence in R\&D expenditures; as expected, the coefficient of the lagged dependent variable is always significant at the $99 \%$ degree of confidence with a value ranging from a minimum of 0.53 to a maximum of $0.77^{18}$. This uniform and highly significant outcome can be interpreted as further confirmation of the presence of cumulative technological trajectories at the level of the single firms (see the discussion in Section 3).

Turning our attention to the main focus of our analysis, on aggregate the estimates reported in Table 2 provide us with weak confirmation of the demand-pull hypothesis: R\&D investment is positively responsive to sales both in the short and long run, with corresponding elasticities equal to 0.22 and 0.54 ; however, in both cases the relationship is only barely significant. On the whole, $R \& D$ expenditures are basically an AR1 process with the demand-pull effect playing a positive but not crucial role. Together with suggestions from previous literature and with the hypotheses put forward in the first part of this section, this result paves the way to a more detailed investigation which can be carried out by splitting our samples in sub-groups of firms. In other words, this aggregate result, although consistent with previous literature, might be not so informative and even conceal more obvious demand-pull effects within particular subsamples of firms characterised by specific features (see points (a) to (g) above).

\section{Insert Table 3}

While more than $85 \%$ of the firms included in the dataset export, they differ as far as export intensity is concerned. In Table 3, the entire sample of 216 firms is split into two groups according to export intensity, measured as the ratio of exports over total sales ${ }^{19}$. As emerges from the comparison of the short- and long-term sales coefficients, the demand-pull hypothesis

\footnotetext{
${ }^{16} 4$ size dummies have been included (< 30 employees in 1997; between 30 and 50; between 50 and 150; > 150).

${ }^{17}$ Two-digit sectoral dummies have been included. For computational reasons, it was impossible to insert sectoral and size dummies into the LSDVC estimates; however, their inclusion in the LSDV estimates affect the values and the significance of the relevant coefficients only negligibly. The regressions reported in Table 8, directly testing the role of size, are not controlled for size dummies; while those in Table 9, testing the role of sectoral belonging, are not controlled for sectoral dummies. Results concerning the coefficients of time, sectoral and size dummies are not reported in the tables, but are available upon request.

${ }^{18}$ The only outlier being in the estimate for firms with a public subsidy (Table 5), where the coefficient turns out to be 0.32 with a $95 \%$ level of statistical significance.

${ }^{19} 45 \%$ being the average export intensity in 1997, firms are divided into two groups depending on whether they are above or below the mean value; unfortunately, no further information about firm internationalization is available in the dataset used in this study.
} 
is significantly confirmed only in the subset of firms with a high export intensity ${ }^{20}$, while the still positive impact of sales becomes not statistically significant in the complementary subsample. Thus hypothesis (a) is not rejected by our empirical exercise; exportation is more demanding in terms of innovation and so is more conducive to increasing R\&D investments; in comparison with the general case, sales including a high proportion of exports are more conducive to innovating.

\section{Insert Tables 4 and 5}

Sales and cash flow should be more crucial in inducing and financing R\&D projects in liquidity-constrained firms and in firms without any kind of public support from tax exemptions and/or subsidies. This seems to be the case in Tables 4 and 5, where firms affected by difficulties in raising credit and which are unsubsidised are seen to be much more sensitive to sales. While the demand-pull hypothesis is significantly supported (95 or 99\%) by the two subsamples made up of constrained firms, it does not emerge as statistically significant, although it is still positive, when using the two complementary sub-samples of firms with softer budget constraints due to availability of external private or public money. These results are consistent with the previous literature and seem to support hypotheses (b) and (c).

\section{Insert Tables 6 and 7}

Firms which can both diversify the risk associated with $R \& D$ expenditures and better internalize future benefits from innovation should be less dependent on present and past sales in deciding the amount to invest in R\&D (see hypotheses (d) and (e) above). While this expectation seems to be clearly confirmed with regard to those firms heading a business group (Table 6), an only barely-significant difference emerges between diversified and not-diversified firms (Table 7). In fact, group leader firms even exhibit a negative short-term impact of sales (although a small but still positive long-term coefficient), while firms not heading a group reveal a 99\% significant short-term innovation elasticity to sales and a rather larger long-term coefficient (0.84 vs 0.36). Similarly, a larger product portfolio (estimates 1, 2, 3 in Table 7) makes firms insensitive to the demand-pull mechanism; nevertheless, the complementary group shows a barely-significant short-term impact of sales: $90 \%$ with a z-statistics equal to 1.94 . Thus the dividing role of diversification emerges as being not particularly striking.

\footnotetext{
${ }^{20}$ See both the short and long-run sale coefficients in the first panel of the table: they show higher values and statistical
} 


\section{Insert Table 8}

In order to obtain two sub-samples that are comparable in terms of number of observations, the dividing size threshold in Table 8 was fixed at the level of fifty employees ${ }^{21}$. Results turn out to be controversial at least to some extent: on the one hand, larger firms seem to be more sensitive to the demand-pull hypothesis both in the short and long run, but on the other hand in the sixth estimate lagged sales turn out to be positive and significant. Bearing this result and the fact that long-term coefficients are positive in both the sub-samples in mind, one can conclude that both large and small firms are demand-pulled in their R\&D decisions, although this result seems to be more obvious in large firms (where in-house R\&D departments are responsible for planning formalised innovation activity), while the response by smaller firms (where R\&D activities are more erratic) appear weaker and delayed.

\section{Insert Table 9}

Finally, firms are grouped together in three sub-samples in Table 9, according to sector belonging $^{22}$. On the whole, no significant differences emerge between the three groups classified according to their technological intensity: while the short-term impact of sales becomes barely significant in the second group, long-term coefficients turn out to be never significant.

\section{Conclusions}

Previous empirical literature does not generally conflict with the demand-pull hypothesis originally proposed by Schmookler (1966). Moreover, demand-pulled innovation emerges as an important interpretative category at the macroeconomic, sectoral and firm levels.

In this paper, a cross-section/time-series analysis is put forward using a panel of 216 Italian manufacturing firms over the period 1995-2000. Checking for firms' fixed effects and for the

\footnotetext{
significances than their counterparts in the second panel of the table.

${ }^{21}$ Very similar results emerge when a threshold of 100 employees is selected; the reader should remember that micro firms (with less than 11 employees) are excluded from our original dataset.

${ }^{22}$ Given our research focus on R\&D and innovation, sectors are considered according to their technological intensity, using the OECD classification system (OECD, 1998). In order to obtain an acceptable number of observations, medium-high and high tech sectors are grouped together in the third group.
} 
autoregressive nature of R\&D investment, the provided microeconometric evidence does not reject the demand-pull hypothesis, yet the role of sales in inducing $R \& D$ expenditures is only barely significant in the overall sample.

In contrast, both the short-term and long-term impacts of demand become obvious and statistically significant for specific groups of firms. More specifically, exporting and liquidityconstrained firms, and firms not receiving public subsidies and not heading a business group, seem to be particularly sensitive to sales when deciding how much to spend on R\&D.

While smaller firms' R\&D expenditures appears to react less and more slowly to the demand evolution in comparison with innovative activity decided in larger companies, no significant differences emerge between firms in low-, medium- or high-tech sectors.

These results have obvious implications in terms of macroeconomic and industrial policies. In particular, expansionary policies, both at the aggregate and sectoral levels, are expected to be conducive to a moderate increase in the aggregate of firms’ R\&D expenditures. However, policies aiming to increasing demand may be particularly important in fostering innovation in specific groups of firms (such as liquidity-constrained firms). Finally, public subsidies emerge as substitutes of expansionary policies in increasing firms’ R\&D expenditures.

From a managerial perspective, R\&D investments appear to be heavily dependent on output, at least in some important groups of firms; this result casts some doubts on the real independence and decision-making autonomy of company R\&D departments.

In more general terms, the conclusion that the demand-pull hypothesis has quite a different explanatory power according to the specific characteristics of the investigated firms paves the way to further research devoted to testing this hypothesis using alternative panel datasets and adequate case studies. 


\section{$\underline{\text { References }}$}

Acs, Z. and Audretsch, D. (1990) Innovation and Small Firms, Cambridge (Mass.): MIT Press.

Anderson, T. W. and Hsiao, C. (1981) Estimation of Dynamic Models with Error Components, Journal of the American Statistical Association, vol.76, pp. 598-606.

Antonelli, C. (1998) The Dynamics of Localized Technological Changes. The Interaction between Factor Costs Inducement, Demand Pull and Schumpeterian Rivalry, Economics of Innovation and New Technology, vol.6, pp. 97-120.

Archibugi, D. and Pianta, M. (1996) Measuring Technological Change through Patents and Innovation Surveys, Technovation, vol.16, pp. 451-68.

Arellano, M. (1989) A Note on the Anderson-Hsiao Estimator for Panel Data, Economics Letters, vol.31, pp. 337-41.

Arellano, M. and Bond, S. (1991) Some Tests of Specification for Panel Data: Monte Carlo Evidence and an Application to Employment Equations, Review of Economic Studies, vol. 58, pp.277-97.

Arellano, M. and Bover, O. (1995) Another Look at the Instrumental Variables Estimation of Errorcomponents Models, Journal of Econometrics, vol. 68, pp.29-51.

Arthur, B. W. (1988) Competing Technologies: An Overview, in Dosi, G. - Freeman, C. - Nelson, R. - Silverberg, G. - Soete, L. (eds.) Technical Change and Economic Theory, London: Pinter, pp. 590-607.

Atkinson, A. B. and Stiglitz, J.E. (1969) A New View of Technological Change, Economic Journal, vol.79, pp. 573-78.

Barlet, C., Duguet, E., Encaoua, D. and Pradel, J. (1998) The Commercial Success of Innovations: An Econometric Analysis at the Firm Level in French Manufacturing, Annales d'Economie et de Statistique, 49/50, pp. 457-78.

Begg, I., Dalum, B., Guerrieri, P. and Pianta, M. (1999) The Impact of Specialization in Europe, in Fagerberg, J. - Guerrieri, P. - Verspagen, B. (eds.) The Economic Challenge for Europe, Cheltenham: Elgar, pp. 21-45.

Blundell, R. and Bond, S. (1998) Initial Conditions and Moment Restrictions in Dynamic Panel Data Models, Journal of Econometrics, vol. 87, pp.115-43.

Bresnahan, T., Brynjolfsson, E. and Hitt, L.M. (2002) Information Technology, Workplace Organization and the Demand for Skilled Labor: Firm-level Evidence, Quarterly Journal of Economics, vol.117, pp. 339-76. 
Brouwer, E. and Kleinknecht, A. (1996) Firm Size, Small Business Presence and Sales in Innovative Products: A Micro-econometric Analysis, Small Business Economics, vol.8, pp. 189-201.

Brouwer, E. and Kleinknecht, A. (1999) Keynes-plus? Effective Demand and Changes in Firmlevel R\&D: An Empirical Note, Cambridge Journal of Economics, vol.23, pp. 385-91.

Bruno, G. S. F. (2005a) Approximating the Bias of the LSDV Estimator for Dynamic Unbalanced Panel Data Models, Economics Letters, vol.87, pp. 361-66.

Bruno, G. S. F. (2005b) Estimation and Inference in Dynamic Unbalanced Panel Data Models with a Small Number of Individuals, CESPRI WP n.165.

Bun, M. J. G. and Kiviet, J. F. (2001) The Accuracy of Inference in Small Samples of Dynamic Panel Data Models, Tinbergen Institute Discussion Paper TI 2001-006/4.

Bun, M. J. G. and Kiviet, J. F. (2003) On the Diminishing Returns of Higher Order Terms in Asymptotic Expansions of Bias, Economics Letters, vol.79, pp. 145-52.

Cassiman, B. and Veugelers, R. (2002) R\&D Cooperation and Spillovers, Some Empirical Evidence from Belgium, American Economic Review, vol.92 , pp. 1169-84.

Cohen, W. M. (1995) Empirical Studies of Innovative Activity, in Stoneman, P. (Ed.) Handbook of the Economics of Innovation and Technical Change, Oxford: Blackwell, pp. 182-264.

Cohen, W. M. and Klepper, S. (1996) A Reprise of Size and R\&D, Economic Journal, vol.106, pp. 925-51.

Cohen, W. M. and Levin, R. C. (1989) Empirical Studies of Innovation and Market Structure, in Schmalensee, R. - Willing, R. D. (eds.) Handbook of Industrial Organization, vol.2, Amsterdam: North-Holland, pp. 1059-107.

Colombo, M. G. and Delmastro, M. (2002) The Determinants of Organizational Change and Structural Inertia: Technological and Organizational Factors, Journal of Economics \& Management Strategy, vol.11, pp. 595-635.

Colombo, M. G. and Garrone, P. (1996) Technological Cooperative Agreements and Firms’ R\&D Intensity: a Note on Causality Relations, Research Policy, vol.25, pp. 923-32.

Cordes, J. J. (1989) Tax Incentives and R\&D Spending: A Review of the Evidence, Research Policy, vol. 18, pp.119-33.

Crépon, B., Duguet, E. and Mairesse, J. (1998) Research, Innovation, and Productivity: An Econometric Analysis at the Firm Level, NBER Working Papers 6696.

David, P. (1985) Clio and the Economics of QWERTY, American Economic Review Proceedings, vol.75, pp. 332-37. 
Dosi, G. (1988) Source, Procedure and Microeconomic Effect of Innovation, Journal of Economic Literature, vol.26, pp. 1120-71.

Dosi, G., Levinthal, D. A. and Marengo, L. (2003) Bridging Contested Terrain: Linking Incentivebased and Learning Perspectives on Organizational Evolution, Industrial and Corporate Change, vol.12, pp. 413-36.

Filatotchev, I., Piga, C. A. and Dyomina, N. (2003) Network Positioning and R\&D Activity: A Study of Italian Groups, R\&D Management, vol. 33, pp.37-48.

Franks, J. and Mayer, C. (1990) Capital Markets and Corporate Control: A Study of France, Germany and the UK, Economic Policy, vol.10, pp. 189-232.

Freeman, C. (1982) The Economics of Industrial Innovation, London: Pinter.

Geroski, P. and Walters, C.F. (1995) Innovative Activity over the Business Cycle, Economic Journal, vol. 105, pp.916-28.

Goodacre, A. and Tonks, I. (1995) Finance and Technological Change, in Stoneman, P. (Ed.) Handbook of the Economics of Innovation and Technical Change, Oxford: Blackwell, pp. 298-341.

Griliches, Z. (1979) Issues in Assessing the Contribution of Research and Development to Productivity Growth, Bell Journal of Economics, vol.10, pp. 92-116.

Griliches, Z. (1995) R\&D and Productivity: Econometric Results and Measurement Issues, in Stoneman, P. (Ed.) Handbook of the Economics of Innovation and Technical Change, Oxford: Blackwell, pp. 52-89.

Hall, B. (1994) Corporate Restructuring and Investment Horizons in the United States, 1976-1987, Business History Review, vol.68, pp. 110-43.

Hall, B., Mairesse, J., Branstetter, L. and Crépon, B. (1999) Does Cash Flow Cause Investment and R\&D? An Exploration using Panel Data for French, Japanese, and United States Scientific Firms, in Audretsch, D - Thurik, R. (eds.) Innovation, Industry Evolution and Employment, Cambridge: Cambridge University Press, pp. 129-56.

Henderson, R. and Cockburn, I. (1996) Scale, Scope, and Spillovers: The Determinants of Research Productivity in Drug Discovery, RAND Journal of Economics, vol.27, pp. 32-59.

Judson, R. A. and Owen, A. L. (1999) Estimating Dynamic Panel Data Models: A Guide for Macroeconomists, Economics Letters, vol.65, pp. 9-15.

Kamien, M. I. and Schwartz, N. L. (1982) Market Structure and Innovation, Cambridge: Cambridge University Press.

Kester, W. C. (1992) Governance, Contracting and Investment Horizons: A Look at Japan and Germany, Journal of Applied Corporate Governance, vol.5, pp. 83-98. 
Kiviet, J. F. (1995) On Bias, Inconsistency, and Efficiency of Various Estimators in Dynamic Panel Data Models, Journal of Econometrics, vol.68, pp. 53-78.

Kiviet, J. F. (1999) Expectation of Expansions for Estimators in a Dynamic Panel Data Model; Some Results for Weakly Exogenous Regressors, in Hsiao, C. - Lahiri, K. - Lee, L.F. Pesaran, M.H. (eds.) Analysis of Panel Data and Limited Dependent Variables, Cambridge: Cambridge University Press, pp. 199-225.

Kleinknecht, A. and Reijnen, J. O. N. (1992) Why Do Firms Cooperate on R\&D? An Empirical Study, Research Policy, vol.21, pp. 347-60.

Kleinknecht, A. and Verspagen, B. (1990) Demand and Innovation: Schmookler Re-examined, Research Policy, vol.19, pp. 387-94.

Malerba, F. (2005) Sectoral Systems of Innovation: A Framework for Linking Innovation to the Knowledge Base, Structure and Dynamics of Sectors, Economics of Innovation and New Technology, vol.14, pp. 63-82.

Malerba, F. and Orsenigo, L. (1996) The Dynamics and Evolution of Industries, Industrial and Corporate Change, vol.5, pp. 51-87.

Nelson, R. R. and Winter, S. (1982) An Evolutionary Theory of Economic Change, Harvard: Harvard University Press.

O’Sullivan, M. (2005) Finance and Innovation, in Fagerberg, J - Mowery, D.C. - Nelson, R.R. (eds.) The Oxford Handbook of Innovation, Oxford: Oxford University Press, pp.240-65.

OECD (1998) OECD Data on Skills: Employment by Industry and Occupation, STI Working Paper 1998/4.

Patel, P. and Pavitt, K. (1995) Patterns of Technological Activity: Their Measurement and Interpretation, in Stoneman, P. (Ed.) Handbook of the Economics of Innovation and Technological Change, Oxford: Blackwell, pp. 14-51.

Pavitt, K. (1984) Sectoral Patterns of Technical Change: Towards a Taxonomy and a Theory, Research Policy, vol.3, pp. 343-73.

Pianta, M. (2001) Innovation, Demand and Employment, in Petit, P and Soete, L. (eds.) Technology and the Future of European Employment, Cheltenham: Elgar, pp. 142-65.

Piga, C. A. and Vivarelli, M. (2003) Sample Selection in Estimating the Determinants of Cooperative R\&D, Applied Economics Letters, vol.10, pp. 243-46.

Piga, C. A. and Vivarelli, M. (2004) Internal and External R\&D: A Sample Selection Approach, Oxford Bulletin of Economics and Statistics, vol.66, pp. 457-82.

Rosenberg, N. (1976) Perspectives on Technology, Cambridge: Cambridge University Press. 
Rosenberg, N. (1982) Inside the Black Box: Technology and Economics, Cambridge: Cambridge University Press.

Ruttan, V. W. (1997) Induced Innovation, Evolutionary Theory and Path Dependence: Sources of Technical Change, Economic Journal, vol.107, pp. 1520-29.

Scherer, F. M. (1982) Demand-pull and Technological Invention: Schmookler Revisited, Journal of Industrial Economics, vol.30, pp. 225-37.

Schmookler, J. (1962) Economic Sources of Inventive Activity. Journal of Economic History, vol.22, pp. 1-10.

Schmookler, J. (1966) Invention and Economic Growth, Cambridge (Mass.): Harvard University Press.

Schumpeter, J.A. (1942) Capitalism, Socialism, and Democracy, New York: Harper and Brothers.

Smith, K. (2005) Measuring Innovation, in Fagerberg, J. - Mowery, D.C. - Nelson, R.R. (eds.) The Oxford Handbook of Innovation, Oxford: Oxford University Press, pp. 148-77.

Stoneman, P. (1979) Patenting Activity: A Re-evaluation of the Influence of Demand Pressures, Journal of Industrial Economics, vol.27, pp. 385-401.

Verbeek, M. (2004) A Guide to modern Econometrics, Chichester: Wiley, 2nd edition.

Veugelers, R. (1997) Internal R\&D Expenditures and External Technology Sourcing, Research Policy, vol.26, pp. 305-15.

Vivarelli, M. (1995) The Economics of Technology and Employment, Cheltenham: Elgar.

Von Tunzelmann, G. N. (1990) Cliometrics and Technology, Structural Change and Economic Dynamics, vol.1, pp. 291-310. 
Table 1 - Descriptive statistics (monetary values at 1995 Italian lire, in millions)

\begin{tabular}{|l|c|c|c|}
\hline & $\begin{array}{c}\text { Mean } \\
\mathbf{( 1 9 9 5 )}\end{array}$ & Std. dev. & Average growth rate (1995-2000) \\
\hline Sales & 27351.22 & 57163.92 & $2.75 \%$ \\
\hline R\&D & 463.2738 & 1822.403 & $5.15 \%$ \\
\hline Employees & 167 & 342.89 & $1.05 \%$ \\
\hline R\&D/Total investments & 0.10 & 0.202 & $4.03 \%$ \\
\hline
\end{tabular}


Table 2: Dependent variable: $\log (R \& D)$

$\left.\begin{array}{llll} & \begin{array}{c}(1) \\ \end{array} & \multicolumn{1}{c}{(2)} & \multicolumn{1}{c}{(3)} \\ & \text { OLS } & \text { LSDV } & \text { LSDVC } \\ \hline \text { Constant } & -0.85 & & \\ & (1.39) & & \\ \log (\mathrm{R} \& \mathrm{D}-1) & 0.64^{* * *} & 0.35^{* * *} & 0.60^{* * *} \\ & (29.48) & (11.63) & (14.23) \\ \log (\text { Sales }) & 0.29 * * * & 0.23^{*} & 0.22^{*} \\ & (2.63) & (1.83) & (1.80) \\ \log (\text { Sales-1) } & -0.03 & 0.03 & -0.003 \\ & (0.31) & (0.24) & (0.02)\end{array}\right\}$ LTE = 0.54*

Notes:

- t-statistics in brackets for OLS and LSDV estimates; z-statistics for LSDVC estimates (bias correction initialised by Arellano-Bond estimator and bootstrapped standard errors): * significant at 10\%; ** significant at 5\%; *** significant at $1 \%$.

- $\mathrm{R}^{2}$ is reported for OLS estimates, F test for LSDV estimates and its significance level.

- Time dummies are always included and not reported; sectoral and size dummies are included in the OLS and LSDV specifications.

- LTE is the Long-term Elasticity; z-statistics in brackets. 
Table 3: Dependent variable: $\log (R \& D)$

Export intensity: estimates (1), (2) and (3) if export/sales >=45\% (mean value); estimates (4), (5) and (6) if export/sales $<45 \%$.

\begin{tabular}{|c|c|c|c|c|c|c|c|c|}
\hline \multicolumn{4}{|c|}{ Export intensity $>=45 \%$} & & \multicolumn{4}{|c|}{ Export intensity $<45 \%$} \\
\hline & $(1)$ & $(2)$ & (3) & & (4) & $(5)$ & (6) & \\
\hline & OLS & LSDV & LSDVC & & OLS & LSDV & LSDVC & \\
\hline Constant & $\begin{array}{l}-1.32 * \\
(1.77)\end{array}$ & & & & $\begin{array}{l}-0.68 \\
(0.94)\end{array}$ & & & \\
\hline $\log (\mathrm{R} \& \mathrm{D}-1)$ & $\begin{array}{l}0.66^{* * * *} \\
(23.49)\end{array}$ & $\begin{array}{l}0.39 * * * \\
(9.89)\end{array}$ & $\begin{array}{c}0.66 * * * \\
(13.68)\end{array}$ & & $\begin{array}{l}0.54 * * * \\
(14.22)\end{array}$ & $\begin{array}{l}0.30 * * * \\
(6.47)\end{array}$ & $\begin{array}{l}0.53^{* * *} \\
(9.54)\end{array}$ & \\
\hline $\log$ (Sales) & $\begin{array}{l}0.43^{* * *} \\
(2.62)\end{array}$ & $\begin{array}{l}0.45^{* *} \\
(2.40)\end{array}$ & $\begin{array}{l}0.43^{* *} \\
(2.53)\end{array}$ & $\mathrm{LTE}=0.76^{*}$ & $\begin{array}{l}0.22 \\
(1.40)\end{array}$ & $\begin{array}{l}0.09 \\
(0.51)\end{array}$ & $\begin{array}{c}0.08 \\
(0.45)\end{array}$ & $\mathrm{LTE}=0.36$ \\
\hline $\log ($ Sales-1) & $\begin{array}{l}-0.14 \\
(0.82)\end{array}$ & $\begin{array}{l}-0.01 \\
(0.06)\end{array}$ & $\begin{array}{l}-0.17 \\
(0.98)\end{array}$ & $(1.68)$ & $\begin{array}{l}0.05 \\
(0.31)\end{array}$ & $\begin{array}{l}0.06 \\
(0.33)\end{array}$ & $\begin{array}{l}0.09 \\
(0.45)\end{array}$ & $(1.02$ \\
\hline $\mathrm{R}^{2}$ and $\mathrm{F}$ test & 0.76 & $153.18 * * *$ & & & 0.60 & $122.49 * * *$ & & \\
\hline Observations & 645 & 645 & 645 & & 435 & 435 & 435 & \\
\hline
\end{tabular}

Notes:

- t-statistics in brackets for OLS and LSDV estimates; z-statistics for LSDVC estimates (bias correction initialised by Arellano-Bond estimator and bootstrapped standard errors): * significant at 10\%; ** significant at 5\%; *** significant at $1 \%$.

- $\mathrm{R}^{2}$ is reported for OLS estimates, F test for LSDV estimates and its significance level.

- Time dummies are always included and not reported; sectoral and size dummies are included in the OLS and LSDV specifications.

- LTE is the Long-term Elasticity; z-statistics in brackets. 


\section{Table 4: Dependent variable: $\log (\mathrm{R} \& D)$}

Liquidity constraints: estimates (1), (2) and (3) when liquidity constraint is present; estimates (4), (5) and (6) when liquidity constraint is not present.

Liquidity constraint (yes)

\begin{tabular}{|c|c|c|c|c|c|c|c|c|}
\hline \multicolumn{4}{|c|}{ Liquidity constraint (yes) } & & \multicolumn{3}{|c|}{ Liquidity constraint (no) } & \\
\hline & (1) & $(2)$ & (3) & & $(4)$ & (5) & (6) & \\
\hline & OLS & LSDV & LSDVC & & OLS & LSDV & LSDVC & \\
\hline Constant & $\begin{array}{l}-0.18 \\
(0.13)\end{array}$ & & & & $\begin{array}{l}-1.16^{*} \\
(1.67)\end{array}$ & & & \\
\hline $\log (\mathrm{R} \& \mathrm{D}-1)$ & $\begin{array}{l}0.60 * * * \\
(8.45)\end{array}$ & $\begin{array}{l}0.33^{* * *} \\
(4.11)\end{array}$ & $\begin{array}{l}0.54 * * * \\
(5.64)\end{array}$ & & $\begin{array}{l}0.63 * * * \\
(26.38)\end{array}$ & $\begin{array}{l}0.35 * * * \\
(10.58)\end{array}$ & $\begin{array}{l}0.61^{* * *} \\
(13.35)\end{array}$ & \\
\hline $\log ($ Sales $)$ & $\begin{array}{l}0.71 * * \\
(2.34)\end{array}$ & $\begin{array}{l}0.75 * * \\
(2.40)\end{array}$ & $\begin{array}{l}0.72^{* *} \\
(2.39)\end{array}$ & $\mathrm{LTE}=0.93^{*}$ & $\begin{array}{l}0.17 \\
(1.34)\end{array}$ & $\begin{array}{l}0.11 \\
(0.80)\end{array}$ & $\begin{array}{c}0.08 \\
(0.57)\end{array}$ & $\mathrm{LTE}=0.44$ \\
\hline $\log ($ Sales-1) & $\begin{array}{l}-0.50 \\
(1.65)\end{array}$ & $\begin{array}{l}-0.11 \\
(0.34)\end{array}$ & $\begin{array}{l}-0.29 \\
(0.88)\end{array}$ & (1.67) & $\begin{array}{l}0.12 \\
(0.95)\end{array}$ & $\begin{array}{l}0.04 \\
(0.31)\end{array}$ & $\begin{array}{l}0.09 \\
(0.68)\end{array}$ & (1.49) \\
\hline $\mathrm{R}^{2}$ and $\mathrm{F}$ test & 0.56 & $77.59 * * *$ & & & 0.71 & $153.42 * * *$ & & \\
\hline Observations & 155 & 155 & 155 & & 900 & 900 & 900 & \\
\hline
\end{tabular}

Notes:

- t-statistics in brackets for OLS and LSDV estimates; z-statistics for LSDVC estimates (bias correction initialised by Arellano-Bond estimator and bootstrapped standard errors): * significant at 10\%; ** significant at 5\%; *** significant at $1 \%$.

- $\mathrm{R}^{2}$ is reported for OLS estimates, $\mathrm{F}$ test for LSDV estimates and its significance level.

- Time dummies are always included and not reported; sectoral and size dummies are included in the OLS and LSDV specifications.

- LTE is the Long-term Elasticity; z-statistics in brackets. 


\section{Table 5: Dependent variable: $\log (R \& D)$}

Subsidy: estimates (1), (2) and (3) if firms have obtained subsidy; estimates (4), (5) and (6) if firms have not obtained subsidy.

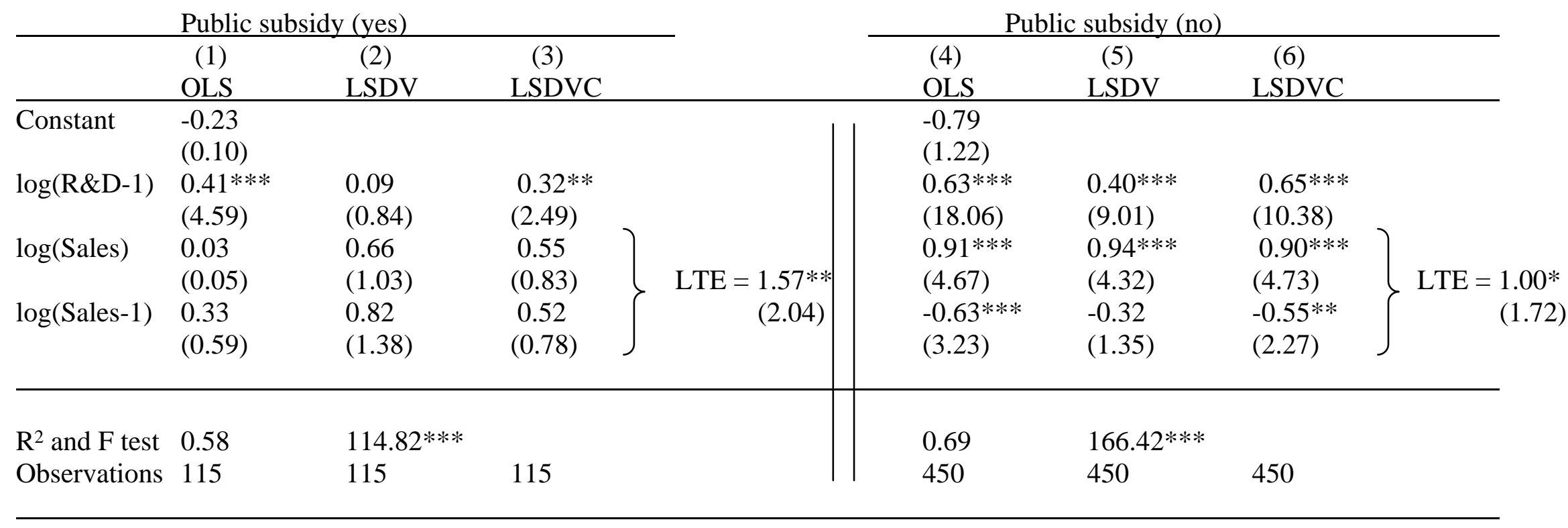

\section{Notes:}

- t-statistics in brackets for OLS and LSDV estimates; z-statistics for LSDVC estimates (bias correction initialised by Arellano-Bond estimator and bootstrapped standard errors): * significant at $10 \%$;** significant at $5 \%$; *** significant at $1 \%$.

- $\mathrm{R}^{2}$ is reported for OLS estimates, $\mathrm{F}$ test for LSDV estimates and its significance level.

- Time dummies are always included and not reported; sectoral and size dummies are included in the OLS and LSDV specifications.

- LTE is the Long-term Elasticity; z-statistics in brackets. 


\section{Table 6: Dependent variable: $\log (\mathrm{R} \& \mathrm{D})$}

Group-head: estimates (1), (2) and (3) if firms are leading a business group; estimates (4), (5) and (6) if firms are not leading a business group.

Firms leading a business group

\begin{tabular}{|c|c|c|c|c|c|c|c|c|}
\hline \multicolumn{4}{|c|}{ Firms leading a business group } & & \multicolumn{4}{|c|}{ Firms not leading a business group } \\
\hline & $(1)$ & (2) & (3) & & (4) & (5) & (6) & \\
\hline & OLS & LSDV & LSDVC & & OLS & LSDV & LSDVC & \\
\hline Constant & $\begin{array}{c}0.33 \\
(0.21)\end{array}$ & & & & $\begin{array}{l}-1.03 * \\
(1.76)\end{array}$ & & & \\
\hline $\log (\mathrm{R} \& \mathrm{D}-1)$ & $\begin{array}{l}0.58 * * * \\
(6.83)\end{array}$ & $\begin{array}{l}0.52 * * * \\
(5.23)\end{array}$ & $\begin{array}{l}0.77 * * * \\
(7.11)\end{array}$ & & $\begin{array}{l}0.64 * * * \\
(28.19)\end{array}$ & $\begin{array}{l}0.32 * * * \\
(10.10)\end{array}$ & $\begin{array}{l}0.57 * * * \\
(12.52)\end{array}$ & \\
\hline $\log ($ Sales) & $\begin{array}{l}-0.39 \\
(1.62)\end{array}$ & $\begin{array}{l}-0.48^{*} \\
(1.95)\end{array}$ & $\begin{array}{l}-0.49 * * \\
(2.03)\end{array}$ & $\mathrm{LTE}=0.36$ & $\begin{array}{l}0.60 * * * \\
(4.48)\end{array}$ & $\begin{array}{l}0.61 * * * \\
(4.01)\end{array}$ & $\begin{array}{l}0.59 * * * \\
(3.85)\end{array}$ & $\mathrm{LTE}=0.84 * * *$ \\
\hline $\log ($ Sales-1) & $\begin{array}{l}0.51 * * \\
(2.12)\end{array}$ & $\begin{array}{l}0.34 \\
(1.31)\end{array}$ & $\begin{array}{l}0.58 * * \\
(2.27)\end{array}$ & $(0.30)$ & $\begin{array}{l}-0.34^{* *} \\
(2.50)\end{array}$ & $\begin{array}{l}-0.06 \\
(0.39)\end{array}$ & $\begin{array}{l}-0.23 \\
(1.54)\end{array}$ & $(2.78)$ \\
\hline $\mathrm{R}^{2}$ and $\mathrm{F}$ test & 0.54 & $111.76^{* * *}$ & & & 0.71 & $145.95 * * *$ & & \\
\hline Observations & 100 & 100 & 100 & & 980 & 980 & 980 & \\
\hline
\end{tabular}

\section{Notes:}

- t-statistics in brackets for OLS and LSDV estimates; z-statistics for LSDVC estimates (bias correction initialised by Arellano-Bond estimator and bootstrapped standard errors): * significant at $10 \%$;** significant at $5 \%$; *** significant at $1 \%$.

- $\mathrm{R}^{2}$ is reported for OLS estimates, $\mathrm{F}$ test for LSDV estimates and its significance level.

- Time dummies are always included and not reported; sectoral and size dummies are included in the OLS and LSDV specifications.

- LTE is the Long-term Elasticity; z-statistics in brackets. 


\section{Table 7: Dependent variable: $\log (R \& D)$}

Diversification: estimates (1), (2) and (3) if first production line is less than 78\% of sales (mean value); estimates (4), (5) and (6) if first production line is more than $78 \%$ of sales.

Diversified production (yes)

Diversified production (no)

\begin{tabular}{|c|c|c|c|c|c|c|c|c|}
\hline & $\begin{array}{c}(1) \\
\text { OLS }\end{array}$ & $\begin{array}{c}(2) \\
\text { LSDV }\end{array}$ & $\begin{array}{c}(3) \\
\text { LSDVC }\end{array}$ & & $\begin{array}{l}(4) \\
\text { OLS }\end{array}$ & $\begin{array}{c}(5) \\
\text { LSDV }\end{array}$ & $\begin{array}{c}(6) \\
\text { LSDVC }\end{array}$ & \\
\hline Constant & $\begin{array}{l}-1.46 \\
(1.62)\end{array}$ & & & & $\begin{array}{l}-0.39 \\
(0.66)\end{array}$ & & & \\
\hline $\log (R \& D-1)$ & $\begin{array}{l}0.64 * * * \\
(17.85)\end{array}$ & $\begin{array}{l}0.39 * * * \\
(7.98)\end{array}$ & $\begin{array}{l}0.64 * * \\
(8.89)\end{array}$ & & $\begin{array}{l}0.62 * * * \\
(21.82)\end{array}$ & $\begin{array}{l}0.32 * * * \\
(8.36)\end{array}$ & $\begin{array}{c}0.56 * * * \\
(10.96)\end{array}$ & \\
\hline $\log ($ Sales) & $\begin{array}{l}0.37 \\
(1.26)\end{array}$ & $\begin{array}{l}0.18 \\
(0.49)\end{array}$ & $\begin{array}{c}0.05 \\
(0.15)\end{array}$ & $\mathrm{LTE}=0.54$ & $\begin{array}{l}0.27 * * \\
(2.20)\end{array}$ & $\begin{array}{l}0.26^{*} \\
(1.91)\end{array}$ & $\begin{array}{c}0.26^{*} \\
(1.94)\end{array}$ & $\mathrm{LTE}=0.50^{*}$ \\
\hline $\log ($ Sales-1) & $\begin{array}{l}-0.06 \\
(0.21)\end{array}$ & $\begin{array}{l}0.29 \\
(0.90)\end{array}$ & $\begin{array}{l}0.14 \\
(0.49)\end{array}$ & $(0.62)$ & $\begin{array}{l}-0.01 \\
(0.13)\end{array}$ & $\begin{array}{l}-0.02 \\
(0.13)\end{array}$ & $\begin{array}{l}-0.04 \\
(0.35)\end{array}$ & $(1.64)$ \\
\hline $\mathrm{R}^{2}$ and $\mathrm{F}$ test & 0.70 & $134.96 * * *$ & & & 0.69 & $140.92 * * *$ & & \\
\hline Observations & 425 & 425 & 425 & & 655 & 655 & 655 & \\
\hline
\end{tabular}

\section{Notes:}

- t-statistics in brackets for OLS and LSDV estimates; z-statistics for LSDVC estimates (bias correction initialised by Arellano-Bond estimator and bootstrapped standard errors): * significant at 10\%; ** significant at 5\%; *** significant at $1 \%$.

- $\mathrm{R}^{2}$ is reported for OLS estimates, $\mathrm{F}$ test for LSDV estimates and its significance level.

- Time dummies are always included and not reported; sectoral and size dummies are included in the OLS and LSDV specifications.

- LTE is the Long-term Elasticity; z-statistics in brackets. 


\section{Table 8: Dependent variable: $\log (R \& D)$}

Size: estimates (1), (2) and (3) if firms have at least 50 employees; estimates (4), (5) and (6) have less than 50 employees.

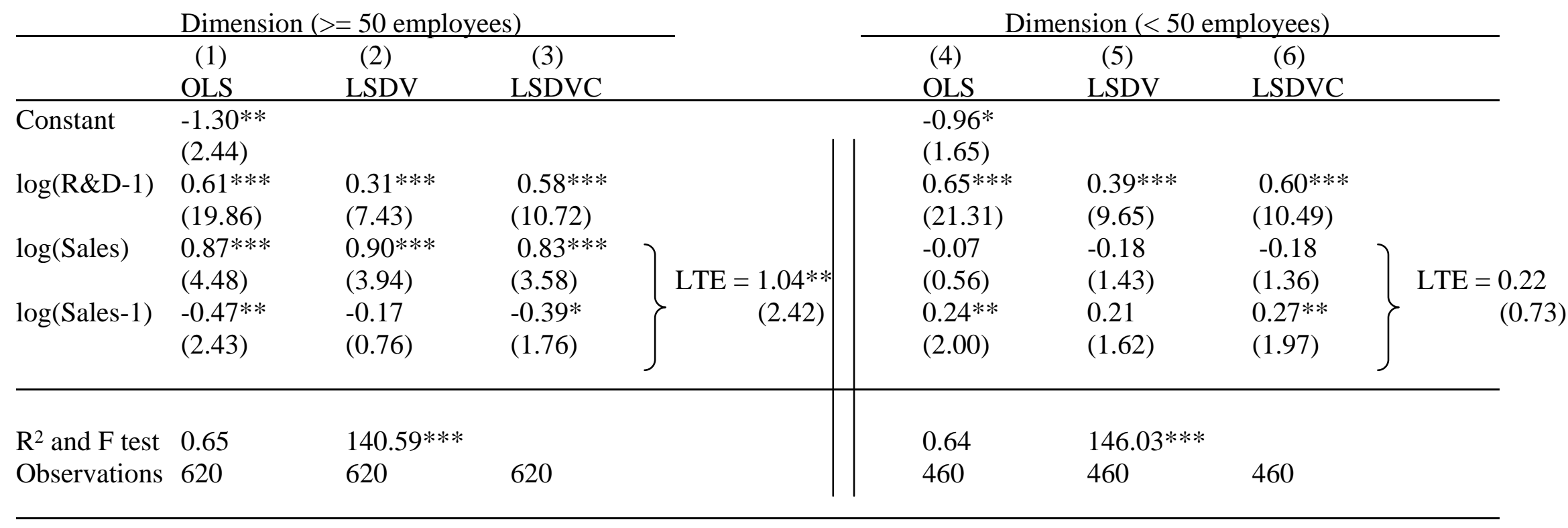

\section{Notes:}

- t-statistics in brackets for OLS and LSDV estimates; z-statistics for LSDVC estimates (bias correction initialised by Arellano-Bond estimator and bootstrapped standard errors): * significant at $10 \%$; ** significant at $5 \%$; *** significant at $1 \%$.

- $\mathrm{R}^{2}$ is reported for OLS estimates, F test for LSDV estimates and its significance level.

- Time dummies are always included and not reported; sectoral dummies are included in the OLS and LSDV specifications.

- LTE is the Long-term Elasticity; z-statistics in brackets. 


\section{Table 9: Dependent variable: $\log (R \& D)$}

Sectors: estimates (1), (2) and (3) if firms belong to low-tech sectors; estimates (4), (5) and (6) if firms belong to medium-low-tech sectors; estimates (7), (8) and (9) if firms belong to medium-high and high-tech sectors.

Low-tech sectors

Medium-low-tech sectors

Medium-high and high-tech sectors

\begin{tabular}{|c|c|c|c|c|c|c|c|c|c|c|c|c|}
\hline & $\begin{array}{c}(1) \\
\text { OLS } \\
\end{array}$ & $\begin{array}{c}(2) \\
\text { LSDV }\end{array}$ & $\begin{array}{c}(3) \\
\text { LSDVC }\end{array}$ & & $\begin{array}{l}(4) \\
\text { OLS }\end{array}$ & $\begin{array}{l}(5) \\
\text { LSDV }\end{array}$ & $\begin{array}{c}(6) \\
\text { LSDVC }\end{array}$ & & \begin{tabular}{|l}
$(7)$ \\
OLS \\
\end{tabular} & $\begin{array}{l}(8) \\
\text { LSDV }\end{array}$ & \multicolumn{2}{|c|}{$\begin{array}{c}(9) \\
\text { LSDVC }\end{array}$} \\
\hline Constant & $\begin{array}{c}0.98 \\
(1.05)\end{array}$ & & & & $\begin{array}{l}-1.54 * * * \\
(3.08)\end{array}$ & & & & \begin{tabular}{|c|}
0.21 \\
$(0.31)$
\end{tabular} & & & \\
\hline $\log (R \& D-1)$ & $\begin{array}{l}0.65 * * * \\
(14.86)\end{array}$ & $\begin{array}{l}0.39 * * * \\
(6.18)\end{array}$ & $\begin{array}{l}0.67 * * * \\
(7.67)\end{array}$ & & $\begin{array}{l}0.68 * * * \\
(25.52)\end{array}$ & $\begin{array}{l}0.32 * * * \\
(8.08)\end{array}$ & $\begin{array}{l}0.57^{* * *} \\
(11.09)\end{array}$ & & $\begin{array}{l}0.66^{* * * *} \\
(13.40)\end{array}$ & $\begin{array}{l}0.37^{* * *} \\
(5.22)\end{array}$ & $\begin{array}{l}0.60 * * * \\
(6.62)\end{array}$ & \\
\hline $\log$ (Sales) & $\begin{array}{l}0.04 \\
(0.26)\end{array}$ & $\begin{array}{c}0.06 \\
(0.32)\end{array}$ & $\left.\begin{array}{c}0.05 \\
(0.28)\end{array}\right)$ & $\mathrm{LTE}=0.58$ & $\begin{array}{l}0.58^{* * * *} \\
(2.77)\end{array}$ & $\begin{array}{l}0.60 * * \\
(2.45)\end{array}$ & $\begin{array}{c}0.55^{*} \\
(1.91)\end{array}$ & $\mathrm{LTE}=0.65$ & $\begin{array}{l}0.35 \\
(1.48)\end{array}$ & $\begin{array}{c}0.28 \\
(0.98)\end{array}$ & $\left.\begin{array}{l}0.22 \\
(0.70)\end{array}\right)$ & $\mathrm{LTE}=0.90$ \\
\hline $\log ($ Sales-1) & $\begin{array}{l}0.03 \\
(0.22)\end{array}$ & $\begin{array}{l}0.06 \\
(0.31)\end{array}$ & $\begin{array}{c}0.14 \\
(0.77)\end{array}$ & (0.95) & $\begin{array}{l}-0.23 \\
(1.10)\end{array}$ & $\begin{array}{l}-0.16 \\
(0.68)\end{array}$ & $\begin{array}{l}-0.27 \\
(1.11)\end{array}$ & (1.33) & $\begin{array}{l}-0.21 \\
(0.88)\end{array}$ & $\begin{array}{c}0.27 \\
(0.97)\end{array}$ & $\left.\begin{array}{l}0.14 \\
(0.46)\end{array}\right\}$ & $(1.37$ \\
\hline $\mathrm{R}^{2}$ and $\mathrm{F}$ test & 0.60 & $80.30 * * *$ & & & 0.69 & $149.92 * * *$ & & & 0.72 & $175.52 * * *$ & & \\
\hline Observations & 250 & 250 & 250 & & 630 & 630 & 630 & & 200 & 200 & 200 & \\
\hline
\end{tabular}

Notes:

- t-statistics in brackets for OLS and LSDV estimates; z-statistics for LSDVC estimates (bias correction initialised by Arellano-Bond estimator and bootstrapped standard errors): * significant at $10 \%$; ** significant at $5 \%$; *** significant at $1 \%$.

- $\mathrm{R}^{2}$ is reported for OLS estimates, $\mathrm{F}$ test for LSDV estimates and its significance level.

- Time dummies are always included and not reported; size dummies are included in the OLS and LSDV specifications.

- LTE is the Long-term Elasticity; z-statistics in brackets. 